\title{
Role of Corticotropin-releasing Factor Signaling in Stress-related Alterations of Colonic Motility and Hyperalgesia
}

\author{
Yvette Taché* and Mulugeta Million \\ CURE/Digestive Diseases Research Center, and Center for the Neurobiology of Stress, Department of Medicine, Division of Digestive Diseases, \\ University of California Los Angeles, and VA Greater Los Angeles Healthcare System, Los Angeles, California, USA
}

The corticotropin-releasing factor (CRF) signaling systems encompass CRF and the structurally related peptide urocortin (Ucn) 1, 2, and 3 along with 2 G-protein coupled receptors, CRF 1 and $C R F_{2}$. CRF binds with high and moderate affinity to CRF 1 and $\mathrm{CRF}_{2}$ receptors, respectively while Ucn1 is a high-affinity agonist at both receptors, and Ucn2 and Ucn3 are selective CRF2 agonists. The CRF systems are expressed in both the brain and the colon at the gene and protein levels. Experimental studies established that the activation of $\mathrm{CRF}_{1}$ pathway in the brain or the colon recaptures cardinal features of diarrhea predominant irritable bowel syndrome (IBS) (stimulation of colonic motility, activation of mast cells and serotonin, defecation/watery diarrhea, and visceral hyperalgesia). Conversely, selective $\mathrm{CRF}_{1}$ antagonists or $\mathrm{CRF}_{1} / \mathrm{CRF}_{2}$ antagonists, abolished or reduced exogenous $\mathrm{CRF}$ and stress-induced stimulation of colonic motility, defecation, diarrhea and colonic mast cell activation and visceral hyperalgesia to colorectal distention. By contrast, the $\mathrm{CRF}_{2}$ signaling in the colon dampened the $\mathrm{CRF}_{1}$ mediated stimulation of colonic motor function and visceral hyperalgesia. These data provide a conceptual framework that sustained activation of the CRF system at central and/or peripheral sites may be one of the underlying basis of IBS-diarrhea symptoms. While targeting these mechanisms by $\mathrm{CRF}_{1}$ antagonists provided a relevant novel therapeutic venue, so far these promising preclinical data have not translated into therapeutic use of $\mathrm{CRF}_{1}$ antagonists. Whether the existing or newly developed $\mathrm{CRF}_{1}$ antagonists will progress to therapeutic benefits for stress-sensitive diseases including IBS for a subset of patients is still a work in progress.

\section{(J Neurogastroenterol Motil 2015;21:8-24)}

Key Words

Colonic motility; Corticotropin-releasing factor; Irritable bowel syndrome; Stress; Visceral pain

Official abbreviations according to UPHARM guideline were used in this review series.

$\mathrm{CRF}$, corticotrophin-releasing factor

$\mathrm{CRF}_{1}$, corticotrophin-releasing factor receptor 1

$\mathrm{CRF}_{2}$, corticotrophin-releasing factor receptor 2

\section{Introduction}

The influence of emotions on the gastrointestinal tract function have been described many centuries ago. ${ }^{1,2}$ The feelings of

Received: December 24, 2014 Revised: None Accepted: December 28, 2014

(c) This is an Open Access article distributed under the terms of the Creative Commons Attribution Non-Commercial License (http://creativecommons. org/licenses/by-nc/3.0) which permits unrestricted non-commercial use, distribution, and reproduction in any medium, provided the original work is properly cited.

*Correspondence: Yvette Taché, PhD Center for Neurovisceral Sciences \& Women's Health, VA Greater Los Angeles Healthcare System, CURE Building 115, Room 117, 11301 Wilshire Blvd, Los Angeles, CA 90073, USA

Tel: +1-310-312-9275, Fax: +1-310-268-4963, E-mail: ytache@mednet.ucla.edu

Financial support: This work was supported by the NIHDDK grants R01 DK-33061 (YT), R01 DK-57236 (YT), R01 DK-078676 (MM), DK-41301 (Animal Models Core, YT, MM), P50 AR-049550 (YT, MM), and VA Merit and Senior Scientist Awards (YT).

Conflicts of interest: None.

Author contributions: Yvette Taché wrote the manuscript; and Mulugeta Million contributed to the writing.

ORCID: Yvette Taché, http://orcid.org/0000-0002-1044-5279. 
"butterflies" in the stomach as well as the "gut wrenching" and nauseous feelings and abdominal pain during or following emotional stress are some of the overt manifestations of the intimate brain-gut connections. ${ }^{3,4}$ The past decades have witnessed an increasing recognition of the role played by the bidirectional interaction between the brain and gut in functional bowel diseases. ${ }^{5-13}$ These interactions occurs through neuronal pathways via the efferent and afferent components of the parasympathetic and sympathetic nervous system, ${ }^{14-16}$ hormonal route including the hypothalamic-pituitary-adrenal (HPA) axis ${ }^{17}$ and/or components of the immune system and the microbiota. ${ }^{18}$ Recent studies also identified a repertoire of neuromediators and receptors in the central nervous system and the gut that are involved in conveying the brain gut interactions in health and diseases. ${ }^{18}$ In particular one of the key mediator in the bodily response to various stressors and the brain-gut interactions is the corticotrophin releasing factor (CRF) pathways family. ${ }^{19-21}$

In this review, we will first briefly outlined the components of the mammalian CRF signaling systems that encompasses CRF peptides, receptors and signaling pathways. We will review preclinical findings on the actions of CRF in the brain and the colon to mimic stress-related stimulation of colonic secretory-motor function and the development of visceral hyperalgesia as well as the role of CRF receptor subtypes in these colonic responses to stress. Lastly, we will address the translational application of these experimental studies to clinical settings with existing clinical trials using $\mathrm{CRF}$ receptor $1\left(\mathrm{CRF}_{1}\right)$ antagonists for irritable bowel syndrome (IBS).

\section{Corticotropin-releasing Facotor Peptides and Receptors}

\section{Corticotropin-releasing Factor Peptides}

The mammalian CRF family of peptides consists of 4 distinct paralogs including $\mathrm{CRF}$, and urocortin (Ucn) 1, Ucn2, and $\mathrm{Ucn} 3{ }^{22} \mathrm{CRF}$ is a 41 -amino acid (a.a.) first isolated from ovine brain by Vale et $\mathrm{al}^{23}$ The peptide structure is highly conserved among a large variety of mammalian species including human, primate, carnivore and rodents. ${ }^{22,24}$ Similar to $\mathrm{CRF}$, the structure of $\mathrm{U}_{\mathrm{cn} 1}$ is highly conserved across mammalian species with rat, mouse and sheep primary sequences sharing $100 \%$ identity, and $95 \%$ with that of human. ${ }^{25}$ Subsequently, the simultaneous cloning of 2 novel putative CRF-related peptides by 2 independent groups ${ }^{26,27}$ resulted in divergent nomenclatures that were normal- ized in the UPHARM guideline. ${ }^{28}$ The mouse Ucn2, a 38-a.a. peptide, shares $34 \%$ homology with human/rat/mouse $(\mathrm{h} / \mathrm{r} / \mathrm{m})$ CRF and $42 \%$ with r/mUcn $1 .{ }^{29}$ Mouse Ucn3 and hUcn3 (also named stresscopin $)^{26}$ share $90 \%$ identity with each other and are more distantly related to $\mathrm{h} / \mathrm{r} / \mathrm{mCRF}, \mathrm{h} / \mathrm{rUcn} 1$, and $\mathrm{mU} \operatorname{cn} 1$ (18\% and $21 \%$ homology respectively). ${ }^{27}$

\section{Corticotropin-releasing Factor Receptors}

$\mathrm{CRF}$ and CRF-related peptides exert their biological actions by binding to 2 specific G-protein coupled receptors (GPCR), $\mathrm{CRF}_{1}$ and $\mathrm{CRF}_{2}$ (415 a.a. and 411 a.a., respectively). ${ }^{22,30}$ The 2 receptors are encoded by 2 distinct genes ${ }^{31}$ and display differential pharmacological and anatomical profiles indicative of distinct functional roles. ${ }^{28,32} \mathrm{CRF}_{1}$ and $\mathrm{CRF}_{2}$ receptors share $70 \%$ identity within their species homologues. ${ }^{28}$ The most variable component is the binding domain that encompasses the $\mathrm{N}$-terminal and the 3 extracellular coils that share only $40 \%$ homology between the 2 receptor subtypes. In their $\mathrm{N}$ extracellular domains, $\mathrm{CRF}$ receptors contain several potential points of $\mathrm{N}$-glycosylation along with several $\mathrm{Cys}$ residues that form disulfide bonds closely associated with their functionality. ${ }^{33}$

As part of class B1 GPCRs containing exon-intron organization, $\mathrm{CRF}$ receptors are subject to extensive alternate splicing. A growing number of $\mathrm{CRF}_{1}$ receptor splice variants $(>10)$ with specific amino acid deletions has been identified in the brain and peripheral tissues including the skin, gut and placenta. ${ }^{34-36}$ The main functional $\mathrm{CRF}_{1}$ receptor is $\mathrm{CRF}_{1 \mathrm{a}}$, which results from the excision of exon 6. This is a unique feature to humans since in most mammals, the exon 6 is absent and the fully active $\mathrm{CRF}_{1}$ receptor protein arises from transcription of 13 exons present within the $\mathrm{CRF}_{1}$ receptor gene sequence. ${ }^{37}$ In humans, the $\mathrm{CRF}_{2}$ gene consists of 12 exons and alternate splicing of exon 1 gives rise to three functional membrane isoforms: $\alpha$ (a), $\beta$ (b) and $\gamma$ (c) differing in the length of their $\mathrm{N}$-terminal domains while in rodents, only the $\mathrm{CRF}_{2 \mathrm{a}}$ and $\mathrm{CRF}_{2 \mathrm{~b}}$ are expressed. ${ }^{28}$ In addition, recently, five variants of the $\mathrm{CRF}_{2 \mathrm{a}}$ receptors have been identified. ${ }^{38} \mathrm{CRF}_{1}$ and $\mathrm{CRF}_{2}$ receptor variant expression is tissue specific, regulated by specific physiological conditions and affected by environmental stimuli. ${ }^{35,38-40}$ There are growing evidence that these isoforms modulates CRF signaling. ${ }^{37,41,42}$

\section{Corticotropin-releasing Factor Ligand-receptor Selectivity}

Radioligand binding and functional studies, established that the $\mathrm{CRF}_{1}$ receptor has high affinity to $\mathrm{h} / \mathrm{r} / \mathrm{mCRF}(1.9 \mathrm{nM})$ and 
$\mathrm{rUcn} 1(0.3 \mathrm{nM})$ but no appreciable binding affinity $(>100 \mathrm{nM})$ to $\mathrm{Ucn}_{\mathrm{c} 2}$ and $\mathrm{Ucn}_{\mathrm{c}}{ }^{28,33}$ In contrast, $\mathrm{rUcn}, \mathrm{h} / \mathrm{mU} \mathrm{cn} 2$ and $\mathrm{mU} \mathrm{cn} 3$ bind $\mathrm{CRF}_{2}$ receptor with greater affinity $(0.3,1.7 / 2.1$, and 5.0 $\mathrm{nM}$ respectively) than $\mathrm{h} / \mathrm{r} / \mathrm{mCRF}(30.7 \mathrm{nM})$, making this receptor subtype highly selective for Ucns signaling. ${ }^{25,29,30,33,43}$ Although $\mathrm{CRF}$ is a preferential $\mathrm{CRF}_{1}$ agonist, no endogenous ligand with selectivity for $\mathrm{CRF}_{1}$ receptors have been identified. Recently, non-natural peptides, namely cortagine and $\operatorname{stressin}_{1}-\mathrm{A}$ have been developed which display selective binding to $\mathrm{CRF}_{1}$ receptors. $^{44,45}$

The structural and mechanistic basis of natural peptide agonists interaction with the $\mathrm{CRF}_{1}$ receptor has been delineated and much advancement has been made as recently reviewed in details. ${ }^{33,46}$ In particular, it is well established that the $\alpha$-helical conformation of CRF peptides in hydrophobic or amphiphilic milieu plays an important role to convey the biological activity of these peptides. The structure-activity relationship based on $\mathrm{CRF}_{1}$ mediated $\mathrm{ACTH}$ release established that the first 21 a.a. of the $\mathrm{N}$-terminal and 8 residues of the $\mathrm{C}$-terminal regions of $\mathrm{CRF}$ are required for the peptide to be biologically active. ${ }^{33}$ The current state-of-knowledge posits a "two-step" model of ligandreceptor interaction whereby the C-terminal portion of $\mathrm{CRF}$ (about 33-40 a.a.) is essential to bind the extracellular N-terminal domain of the $\mathrm{CRF}_{1}$ receptor ( $\mathrm{N}$-domain). This brings the $\mathrm{N}$-terminus (about 10 a.a.) of the peptide in the optimal orientation to bind to the J-domain which is formed by the seven transmembrane helices and three extracellular loops responsible for the coupling to Gs- and Gi-proteins. ${ }^{33,34}$ Recent studies also indicate that the molecular basis for ligand selectivity involves a single amino acid difference in the N-terminal extracellular domains of the receptors $\left(\mathrm{CRF}_{1}\right.$ Glu104/ $\mathrm{CRF}_{2 \mathrm{a}}$ Pro-100) at a site proximate to peptide residue 35 (Arg in $\mathrm{CRF} / \mathrm{Ucn} 1$, Ala in $\mathrm{U} \operatorname{cn} 2 / 3)^{47}$

In contrast to the $\mathrm{CRF}_{1}$ receptor isoforms, ${ }^{34,36}$ binding characteristics of $\mathrm{CRF}$ receptor splice variants, $\mathrm{CRF}_{2 \mathrm{a}}, \mathrm{CRF}_{2 \mathrm{~b}}$, and $\mathrm{CRF}_{2 \mathrm{c}}$ are almost identical with high affinity for $\mathrm{Ucn}_{\mathrm{c}}, \mathrm{Ucn} 2$, and $\mathrm{Ucn} 3$, and lower affinity for $\mathrm{r} / \mathrm{hCRF} .^{27,48-50}$ Unexpectedly, the mouse soluble $\mathrm{CRFR}_{2 \mathrm{a}}$ isoform displays very low affinity for $\mathrm{Ucn} 2$ and $\mathrm{Ucn} 3$ while binding to $\mathrm{Ucn} 1$ ( Ki $6.6 \mathrm{nM}$ ) and to a lesser extent to CRF (23 nM). Activation of this isoform also inhibits cAMP and extracellular signal-regulated kinases 1 (ERK1/2)-p42,44 responses to Ucn1 and CRF. ${ }^{41}$ In contrast, rat $\mathrm{CRF}_{2 \mathrm{a} \text {-tr }}$ binds with low affinity to $\mathrm{CRF}$ (Kd $12.7 \mathrm{nM}$ ) while displaying no affinity to $\mathrm{U} \mathrm{cn} 1 .^{51}$

\section{Corticotropin-releasing Factor Receptor Signaling}

As members of the class $\mathrm{B} 1$ class of GPCR, CRF receptors are primarily coupled to $G_{\alpha s}$, the hallmark feature known to this GPCR subfamily. Ligand receptor interaction initiates several intracellular cAMP-dependent signaling cascades leading to acute post-translational modification of target proteins by protein kinase $\mathrm{A}(\mathrm{PKA})$ in the cytoplasm and gene transcription regulation by cAMP response element-binding proteins activation in the nucleus. ${ }^{46}$ However, CRF ligand-receptor interaction can diverge to a plethora of downstream intracellular effectors, such as guanyl cyclase, ERK1/2, nuclear factor kappa-light-chain-enhancer of activated $\mathrm{B}$ cells $(\mathrm{NF}-\mathrm{kB})$ transcription factor, ion channels, tyrosine hydroxylase phosphorylation and glycogen synthase kinase 3 beta/Wnt/b-catenin pathway. ${ }^{34,46,52}$ In general, while $\mathrm{CRF}_{1}$ and $\mathrm{CRF}_{2}$ receptor signaling is mediated primarily through $\mathrm{G}_{\alpha \mathrm{s}}$ and thus cAMP as the second messenger, ${ }^{33,34}$ a low affinity binding site for the peptide ligand can also activate $G_{i-}$ and $G_{q / 11}$-coupled state. ${ }^{46,53}$ The occurrence of various signaling pathways is cell type and ligand specific. ${ }^{46}$ The several described signaling pathways of $\mathrm{CRF}$ ligand-receptor interaction have been delineated in several cell lines or in specific organs, ${ }^{46}$ and more recently, in colonic endocrine, neuronal or epithelial cells. ${ }^{36,54,55}$

\section{Corticotropin-releasing Factor Receptor Antagonists}

Key to the assessment of the role of endogenous CRF ligands and $\mathrm{CRF}$ receptors in the stress response was the early development of several N-terminally truncated and substituted CRF analogs developed by Jean E Rivier. ${ }^{56}$ Overall, four groups of CRF receptor antagonists have been developed which include the specific, nonselective peptide $\mathrm{CRF}_{1}$ and $\mathrm{CRF}_{2}$ receptor antagonists namely $\alpha$-helical $\mathrm{CRF}_{9-41}, \mathrm{D}-\mathrm{Phe}^{12} \mathrm{CRF}_{12-41}$, astressin and the acting astressin-B; the selective peptide $\mathrm{CRF}_{2}$ receptor antagonists, anti-sauvagine and astressin $2-\mathrm{B} ;{ }^{56}$ the recently developed selective peptide $\mathrm{CRF}_{1}$ antagonist, YAM19 which represents the only peptide $\mathrm{CRF}_{1}$ receptor antagonist ${ }^{57}$; and the numerous non-peptide $\mathrm{CRF}_{1}$ antagonists. ${ }^{33,58,59}$ All these antagonists have been widely used as tools to determine the CRF receptor subtypes mediating stress-induced behavioral, endocrine and autonomic responses. ${ }^{58,60,61}$ While upon peripheral administration, the non-peptide $\mathrm{CRF}_{1}$ receptor antagonists readily cross the blood-brain barrier as recently reviewed, ${ }^{59,62}$ the peptide CRF antagonists have no or very low ability to cross the barrier. ${ }^{63}$ This al- 
lows us to delineate the central and/or peripheral role of CRF receptor upon injection of antagonists into the brain or the periphery respectively. For instance, we showed that intravenous (iv) injection of astressin, at a dose that blocked intravenous CRF-induced delayed gastric emptying, did not influence CRF injected into cisterna magna-induced delayed gastric transit in rats. ${ }^{64}$ Likewise, $\alpha$-helical $\mathrm{CRF}_{9-41}$ infused intravenously did not influence the suppression of pentagastrin stimulated acid secretion evoked by intracerebroventricular (icv) injection of CRF, while, injected icv, the antagonist blocked the icv CRF action in rats. ${ }^{65}$

\section{Role of Brain Corticotropin-releasing Factor Receptor 1 in Stress-related Stimulation of Colonic Motor Function}

\section{Brain Distribution of Corticotropin-releasing Factor-Cordicotropin-releasing Factor Receptor 1}

CRF peptides and receptors are widely distributed in the brain including specific regions linked with anxiogenic and digestive behaviors. ${ }^{32,66-69}$ In particular, major sites of CRF mRNA and $\mathrm{CRF}$ immunoreactivity are located in the paraventricular nucleus (PVN) of the hypothalamus, cerebral cortex, amygdalar-hippocampal complex and pontine Barrington's nucleus in rodents and humans. ${ }^{67,68}$ With regards to the brain distribution of CRF receptors, dense $\mathrm{CRF}_{1}$ receptor expression is found in the forebrain, subcortical limbic structures (more prominently in the septal region) and amygdala, whereas the expression in the hypothalamus is low under basal conditions but markedly up-regulated by stress. ${ }^{32,70,71}$ Moreover, $\mathrm{CRF}_{1}$ receptors at the gene and protein levels are prominently expressed in the anterior and intermediate lobe of the pituitary. ${ }^{60}$

\section{Activation of Brain Corticotropin-releasing Factor Receptor 1 Is Involved in the Colonic Response to Stress}

Consistent with the brain localization of $\mathrm{CRF} / \mathrm{CRF}_{1}$ signaling pathway, convergent preclinical reports point to the role of central $\mathrm{CRF}_{1}$ receptors in stress-related stimulation of colonic secretory motor function. ${ }^{61}$ First, CRF and Ucn1 injected into the cerebrospinal fluid induces the occurrence of colonic spike burst activity, acceleration of colonic transit, decreased in colonic fluid absorption, stimulation of defecation, and induction of diarrhea in freely moving rats, mice and gerbils, mimicking the effects of ex- posure to acute stressors whereas Ucn2 and Ucn3 under the same conditions have no effect. ${ }^{72-80}$ Secondly, pharmacological blockade of $\mathrm{CRF}$ receptors using icv injection of peptide $\mathrm{CRF}_{1} / \mathrm{CRF}_{2}$ receptor antagonists, $\alpha$-helical $\mathrm{CRF}_{9-41}, \mathrm{D}-\mathrm{Phe}^{12} \mathrm{CRF}_{12-41}$, or astressin inhibited the stimulation of defecation, as well as the increase in wet stool and colonic spike-bursts induced by icv CRF, wrap restraint, water avoidance stress (WAS) and/or conditioned fear. ${ }^{72,75,76,81-86}$ Furthermore, the $\mathrm{CRF}_{1}$ receptor antagonists, CP-154,526, CRA 1000, NBI-27914, NBI-35965, antalarmin, JTC-017, NGD 98-2, and NGD 9002 injected either centrally or peripherally (as they cross the blood brain barrier), dampened icv CRF and various stressors including acute restraint, WAS, elevated plus maze, social intruder or exposure to chronic heterotypic stressors (WAS, forced swim, cold restraint, and restraint-induced stimulation of colonic motor function). ${ }^{74,80,84,87-90}$ By contrast the selective $\mathrm{CRF}_{2}$ antagonist, astressin ${ }_{2}-\mathrm{B}$ injected centrally at doses that blocked $\mathrm{CRF}_{2}$ receptor-mediated inhibition of gastric emptying, did not alter restraint stress-related defecation in mice or chronic heterotypic stress. ${ }^{74,89}$ In addition $\mathrm{CRF}_{1}$ receptor knockout mice showed significantly less defecation in an open field test than did the wild-type littermates. ${ }^{91}$ Importantly, brain $\mathrm{CRF}_{1}$ receptors are not involved in the basal and postprandial regulation of colonic motor function under non-stress conditions. ${ }^{92}$

\section{Brain Sites of Action of Corticotropin-releasing Factor-induced Stimulation of Colonic Motor Function}

Brain nuclei responsive to $\mathrm{CRF}$ leading to the stimulation of colonic motor function (increased in tonic and phasic colonic motility, decreased colonic transit time and induction of watery fecal output) have been localized in the hypothalamus (PVN, arcuate nucleus) and pontine areas, namely the locus coeruleus (LC)/ Barrington nucleus complex, ${ }^{93-96}$ which are also brain nuclei involved in central CRF-induced anxiety and depression. ${ }^{97,98}$ Anatomical support for the role of pontine and PVN CRF signaling pathways in the regulation of pelvic organ functions came from tracing studies showing that a proportion of CRF immunoreactive neurons in the Barrington's nucleus and PVN are linked transynaptically to the colon. ${ }^{99,100}$ Of interest is the growing pharmacological evidence that a number of brain peptides influencing food intake, such as neuropeptide $Y$, glucagon-like peptide, cocaine- and amphetamine-regulated transcript (CART), and ghrelin, act in the brain to stimulate colonic motor function through CRF receptor activation-dependent mechanisms in the 
hypothalamus. ${ }^{101-106}$

\section{Brain Corticotropin-releasing Factor and Colonic Response: Peripheral Mechanisms}

Peripheral mechanisms involved in colonic secretory motor stimulation in response to central CRF or stress (restraint or WAS) is independent from the activation of the HPA axis and brought about through the activation of sacral parasympathetic outflow and related input to the enteric nervous system (ENS) activity. $^{73,82,85}$ The ganglionic blocker, chlorisondamine prevented and subdiaphragmatic vagotomy attenuated the stimulation of colonic transit, phasic and tonic contractions, and defecation induced by CRF injected icv or into the PVN while bretylium (noradrenergic blocker) had no effect. ${ }^{73,95,96,103}$ Effector mechanisms within the colon involved parasympathetic cholinergic mediated activation of colonic serotonin (5-HT) interacting with $5-\mathrm{HT}_{3}$ and $5-\mathrm{HT}_{4}$ receptors. This is supported by the increase in 5-HT content in the feces of the rat proximal colon in response to icv $\mathrm{CRF}^{107}$ and pharmacological approach using $5-\mathrm{HT}_{3}$ antagonists (granistron, ramosteron, ondansetron and azasetron), the $5-\mathrm{HT}_{4}$ antagonist, SB-204070 and the muscarinic antagonist, atropine that all blocked icv CRF-induced colonic motor stimulation and decreases in colonic fluid loss. ${ }^{76,78,88,107}$

\section{Role of Colonic Corticotropin-releasing Factor Receptors in Stress-related Stimulation of Colonic Motor Function -}

\section{Activation of Peripheral Corticotropin- releasing Factor Receptor 1 Contributes to the Colonic Response to Stress}

Functional studies showed that CRF and Ucn1 injected peripherally are as potent as injected centrally to increase propagative clustered spike-burst activity in the proximal colon and to stimulate distal colonic transit, defecation and to induce prominent diarrhea in rodents. ${ }^{54,72,76,108-115}$ The stimulation of colonic secretory-motor function after peripheral administration of CRF or $\mathrm{U}_{\mathrm{cn} 1}$ involves $\mathrm{CRF}_{1}$ receptors in rats and mice. This is supported by the fact that elective $\mathrm{CRF}_{1}$ agonist, cortagine or stres$\sin 1$ injected intraperitoneally stimulates colonic motor function and induces diarrhea while the $\mathrm{CRF}_{2}$ agonists, $\mathrm{Ucn} 2$ has not effect under the same conditions. $54,108,110,111,116,117$

The colonic $\mathrm{CRF}_{-} \mathrm{CRF}_{1}$ signaling may have relevance as peripheral effector of the acute stress response. There is evidence that stressors that stimulate colonic motor function such as endotoxin or early maternal separation upregulates $\mathrm{CRF}_{-} \mathrm{CRF}_{1}$ signaling in the colon. ${ }^{118,119}$ In addition peripherally injected peptide antagonists $\alpha$-helical $\mathrm{CRF}_{9-41}$, astressin or astressin-B blocked or blunted the stimulation of distal colonic transit and high amplitude high frequency contraction and fecal pellet output induced by acute restraint or WAS in rats or mice. ${ }^{72,76,110,113,115}$

\section{Corticotropin-releasing Factor Receptor 1 in the Colon: Mechanisms to Stimulate Propulsive Motor Function}

Recent studies establishing the expression of both $\mathrm{CRF}_{1}$ receptor and ligands in the colon at the gene and protein levels in various cells including neuronal (ENS), endocrine (enterochromaffin cells) and immune cells (mast cells, eosinophiles, T-helper lymphocytes in the lamina propria) in rodents. ${ }^{54,116,118,120-122}$ This provides a neuroanatomical substrata pointing toward a local role CRF signaling pathways as recently reviewed. ${ }^{123}$

Consistent with a local action, intraperitoneal injection of CRF-induced colonic stimulation is not affected by ganglion blockade, in contrast with the evidence on the role of the autonomic nervous system in mediating central CRF-induced stimulation of colonic propulsive motor function. ${ }^{73,96}$ Further support for direct action within the colon came from in vitro studies in isolated colonic rat preparations or isolated rat colonic muscle strips where CRF increased basal myoelectrical peristaltic activity and phasic contractions and electric field stimulation off-contractions. $^{110,122,124}$

Convergent evidence substantiates that the peripheral stimulatory action of CRF or Ucn1 involved the increase ENS neuronal activity in cholinergic, nitrergic and serotonergic neurotransmission promoting peristaltic through the activation of $\mathrm{CRF}_{1}$ receptors on ENS in rats or guinea pigs. ${ }^{54,107,116,122,125}$ First, the use of laser captured combined with reverse transcriptase polymerase chain reaction or immunohistochemical detection in myenteric whole mount preparation of the colon revealed that $\mathrm{CRF}_{1}$ receptors are primarily expressed at the gene and protein levels on myenteric neurons compared with other layers of the rat or guinea colon under basal conditions. ${ }^{54,116,122,125}$ Second, the neuronal blocker, tetrodotoxin abolished Ucn1-evoked phasic contractions in rat colonic smooth muscle strips, ${ }^{122}$ indicative of an ENS mediated component. Third, when injected intraperitoneally, $\mathrm{CRF}$ in rats or partial restraint in mice induces Fos expression, a marker of neuronal activation, ${ }^{126}$ in $\mathrm{CRF}_{1}$ receptor expressing cholinergic and nitrergic myenteric neurons in 
the proximal colon while $\mathrm{Ucn} 2$ under the same conditions did not induce Fos. ${ }^{54,116,117,127,128}$ It is to note that atropine, a muscarinic blocker, does not affect intraperitoneal CRF-induced neuronal activation in colonic myenteric ganglia, indicating that the Fos response is not secondary to the activation of muscarinic receptors either on the myenteric ganglia (which possess both nicotinic and muscarinic receptors) or on colonic smooth muscle cells but rather to a direct effect on enteric neurons. ${ }^{127}$ Additional support came from electrophysiological recording showing that direct administration of CRF or Ucn1 onto colonic myenteric and submucosal plexus preparations of guinea pig excites both myenteric and submucosal neurons through $\mathrm{CRF}_{1}$ receptor. ${ }^{125,129,130}$ Other studies in rat submucosal neuron preparation showed that CRF induces a tetradotoxin sensitive and $\mathrm{CRF}_{1}$ receptor mediated neuronal activation monitored by the increase in intracellular calcium. $^{131}$

Other peripheral molecular pathways of the potent stimulation of colonic secretory motor function by peripheral injection of CRF may include the crosstalk between the enteric neuroendocrine and immune systems. CRF added in vitro to rat colonic section up-regulates IL-6 in the colonic tissues and potentiates IL-6 induced submucosal neuron activity of the colon through $\mathrm{CRF}_{1}$ receptor. ${ }^{131}$

\section{Corticotropin-releasing Factor Receptor 2 in the Colon: Modulation of Stress-related Stimulation of Propulsive Motor Function}

The $\mathrm{CRF}_{2}$ ligands, $\mathrm{Ucns}$ and $\mathrm{CRF}_{2}$ receptors are also expressed in rodent colon. ${ }^{54,55,123,132-135}$ The $\mathrm{CRF}_{2}$ receptors are localized at the gene and protein levels in cells of the rodent colonic $\mathrm{ENS}^{54}$ although less prominently than that $\mathrm{CRF}_{1}$ receptor ${ }^{130,131}$ and human colonic lamina propria mononuclear cells, ${ }^{135}$ subepithelial mast cells ${ }^{136}$ and epithelial cells ${ }^{55}$ supporting a local action to influence neuronal and immune responses.

Recent studies indicate that intraperitoneal pretreatment with Ucn2 acting through $\mathrm{CRF}_{2}$ receptors inhibits peripheral CRF-or Ucn1 induced stimulation of colonic motor function while pre-treatment with astressin $2-\mathrm{B}$ or genetic deletion of $\mathrm{CRF}_{2}$ in mice exacerbated the restraint stress or intraperitoneal $\mathrm{CRF}$ and Ucn 1 induced stimulatory colonic responses. ${ }^{54,137}$ These data are indicative that acute stress-related colonic stimulation engages not only the colonic $\mathrm{CRF}_{1}$-mediated enteric stimulatory pathway but also $\mathrm{CRF}_{2}$ to dampen the colonic response to stress. This interaction is occurring in myenteric neurons as evidenced by the localization of $\mathrm{CRF}_{2}$ receptors on $\mathrm{CRF}_{1}$ expressing myenteric neurons and the reduction of CRF-induced ERK1/2 signaling in the rat colon myenteric primary neurons by $\mathrm{CRF}_{2}$ receptors activation. $^{54}$ The differential effects of $\mathrm{CRF}_{1}$ and $\mathrm{CRF}_{2}$ receptors are also reported to exist in stress-induced intestinal mucosal barrier function alterations. In pigs exposed to early-weaning stress, intestinal barrier dysfunction and hypersecretion is mediated through $\mathrm{CRF}_{1}$ activation whereas activation of peripheral $\mathrm{CRF}_{2}$ plays a protective role in the alterations of intestinal barrier function in response to early life stress. ${ }^{138}$

\section{Role of Brain Corticotropin-releasing Factor Receptors in Stress-related Visceral Hyperalgesia}

\section{Corticotropin-releasing Factor Receptor 1 Signaling Is Involved in the Stress-related Hyperalgesia}

Gué et $\mathrm{al}^{139}$ provided the first evidence that CRF injected icv induced visceral hyperalgesia to colorectal distention (CRD) in rats, mimicking the response induced by partial restraint stress. Furthermore, the icv injection of the $\mathrm{CRF}_{1} / \mathrm{CRF}_{2}$ antagonists, $\alpha$-helical $\mathrm{CRF}_{9-41}$ prevented the effects of restraint pointing to the involvement of central CRF signaling in acute stress-related development of visceral hyperalgesia. ${ }^{139}$ Subsequent studies using selective $\mathrm{CRF}_{1}$ antagonists, ${ }^{59}$ namely NBI-35965, NBI-27914, NBI-30775, CP-154,526, CP-376395, antalarmin, JTC-017, DMP-696, NGD 98-2, or NGD 9002 supported the involvement of $\mathrm{CRF}_{1}$ subtype in the hyperalgesic response to $\mathrm{CRD}$ induced by icv CRF injection ${ }^{80,140}$ or in a variety of experimental models inducing visceral hyperalgesia including acute or repeated exposure to WAS alone or combined with neonatal maternal separation, consecutive sets of nociceptive CRD, repeated daily CRD 6 weeks after the development of colitis, intracolonic infusion of $0.5 \%$ acetic acid, or performing the CRD in a high-anxiety rat strain, the Wistar Kyoto (WKO). ${ }^{80,90,140-152}$ Likewise in $\mathrm{CRF}_{1}$ receptor knockout mice, the visceral motor response to phasic CRD is reduced. ${ }^{149}$ These consistent pre-clinical reports indicate that $\mathrm{CRF}_{1}$ signaling plays a critical role in the visceral hyperalgesia occurring in different contexts: early life adverse events, repeated psychological stress in adulthood, chronic high anxiety as well as peripherally initiated mechanisms associated with previous colonic inflammation or repeated nociceptive CRD.

By contrast, the central effects of $\mathrm{CRF}_{2}$ receptor activation on 
visceral pain are scant. In a recent study Lee et $\mathrm{al}^{152}$ indicates that perfusion of selective $\mathrm{CRF}_{2}$ receptor antagonist, astressin 2 - $\mathrm{B}$ into the anterolateral BNST reduced visceral motor response to low $\mathrm{CRD}$ pressure in rats. Further studies are needed to assess the contribution of brain $\mathrm{CRF}_{2}$ receptors in the modulation of visceral pain.

\section{Mechanisms Involved in Corticotropin-releasing Factor Receptor 1 Mediated Prevention of Visceral Hyperalgesia}

Brain sites responsive to $\mathrm{CRF}$ and $\mathrm{CRF}_{1}$ antagonist to influence stress-related visceral hyperalgesia encompass the hippocampus, anterior lateral bed nucleus of the stria terminalis (BNST) and the central amygdala (CeA). One study showed that the $\mathrm{CRF}_{1} / \mathrm{CRF}_{2}$ antagonists, $\alpha$-helical $\mathrm{CRF}_{9-41}$ microinjected into the hippocampus or peripheral injection of the $\mathrm{CRF}_{1}$ antagonist, JTC-017 decreased abdominal contraction frequency evoked by nociceptive tonic $\mathrm{CRD}$ along with the anxiety response to $\mathrm{CRD}$ in rats. ${ }^{90}$ There is also recent evidence that the $\mathrm{CRF}_{1}$ antagonist, CP-376395 microinjected into the anterolateral BNST after repeated WAS reduced the visceral motor response to CRD. ${ }^{152}$ Converging studies also point $\mathrm{CeA}$ as a responsive site to the $\mathrm{CRF}_{1}$ antagonist, $\mathrm{CP}-376395$ to reduced visceral hyperalgesia to CRD in the WKO rat strain. ${ }^{153}$ Conversely CRF microinjected into the $\mathrm{CeA}$ increased sensitivity to $\mathrm{CRD}$ performed at 20 to $80 \mathrm{mmHg}$ in Wistar rats through $\mathrm{CRF}_{1}$ receptor as shown by the blockade of CRF action by the intra-CeA injection of CP-154,526. ${ }^{154}$ Neuroanatomical evidence that CRF is densely expressed in cell bodies and axon terminals of cortical amygdala projecting to widespread regions of the basal forebrain and pontine/brainstem including the locus coeruleus (LC) support the notion that endogenous $\mathrm{CRF}$ acts as a ligand to act on $\mathrm{CRF}_{1}$ receptor in the CeA. ${ }^{155,156}$ Moreover CRF-like immunoreactivity and gene expression in $\mathrm{CeA}$ are increased in response to $\mathrm{CRD}^{157}$ and various conditions inducing visceral pain or hyperalgesia. ${ }^{158-161}$

The underlying mechanisms through which blockade of brain $\mathrm{CRF}_{1}$ receptor activation influences the development of stress or mechanosensitization-related visceral hyperalgesia are still not fully understood. One component may involve the dampening of pontine noradrenergic output from the visceral to the forebrain. Recent electrophysiologic reports in anesthetized rats showed that the peptide antagonist $\mathrm{D}-\mathrm{Phe}^{12} \mathrm{CRF}_{12-41}$, or astressin injected into the cerebrospinal fluid or directly into the $\mathrm{LC}$ and the selective $\mathrm{CRF}_{1}$ antagonist, NBI-35965, injected iv prevented the activation of the LC noradrenergic neurons responsive to both central injection of CRF and CRD. ${ }^{162-164}$ Consistent with electrophysiological demonstration of LC noradrenergic silencing by $\mathrm{CRF}$ receptor antagonists, the $\mathrm{CRF}_{1}$ antagonist, JTC-0 17 reduces noradrenaline release in the hippocampus and $\mathrm{CeA}$ induced by CRD. ${ }^{90,154}$ The release of noradrenaline in the cortical and limbic rostral efferent projections from the $\mathrm{LC}$ or $\mathrm{CeA}^{165}$ is known to induce arousal and anxiogenic responses along with hypervigilence to visceral input which is a commonly found feature in IBS patients. ${ }^{166,167}$

\section{Role of Colonic Corticotropin-releasing Factor Receptors in Stress-related Hyperalgesia}

\section{Corticotropin-releasing Factor Receptor 1}

Recent reports suggest that enhanced $\mathrm{CRF} / \mathrm{CRF}_{1}$ receptor signaling in the colon, in addition to central activation, bears relevance as part of the peripheral efferent components responsible for the induction of visceral hyperalgesia. There is evidence that peripheral injection of $\mathrm{CRF}$ induces visceral hypersensitivity to $\mathrm{CRD}$, an effect reproduced by the intraperitoneal administration of the selective $\mathrm{CRF}_{1}$ agonist, cortagine in rats and mice. ${ }^{117}$ Conversely in rats repeatedly exposed to WAS for 10 days, peripheral injection of peptide CRF antagonist astressin before each stress session prevented the development of visceral hyperalgesia supporting the participation of a peripheral component to the development of visceral hyperalgesia. ${ }^{144}$ This is further supported by the demonstration that the visceral hyperalgesia induced by cortagine injected peripherally is abolished by peripheral, but not central, injection of astressin at an equivalent dose. ${ }^{117}$

Several mechanisms are involved in the visceral hyperalgesia linked with the activation of $\mathrm{CRF}_{1}$ receptors in the colon. Peripheral CRF induces colonic mast cells degranulation. ${ }^{168-170}$ which can in turn lead to the release of several preformed or newly synthesized mediators eg, histamine, tryptase, prostaglandin $\mathrm{E}_{2}$, and nerve growth factor known to activate or sensitize sensory afferents. ${ }^{171,172}$ The involvement of colonic mast cell is further supported by the use of mast cell stabilizer, doxantrazole, that prevented acute stress-induced colonic hypersensitivity to a second set of CRD. ${ }^{139,169}$ Additionally, peripheral CRF signaling activation disrupts the intestinal epithelial barrier and $\mathrm{CRF}_{1}$ receptor antagonists block stress-induced increases in intestinal permeability. ${ }^{123,168,173}$ Such CRF receptor mediated alteration of 
intestinal permeability increases the penetration of soluble factors (antigens) into the lamina propria, which can result in nociceptors sensitization. ${ }^{174}$ Increased intestinal permeability is indeed a phenomenon that appears as a prerequisite for the development of visceral hyperalgesia in rodents. ${ }^{175}$

\section{Corticotropin-releasing Factor Receptor 2}

In contrast, activation of $\mathrm{CRF}_{2}$ by intraperitoneal injection of the selective $\mathrm{CRF}_{2}$ peptide agonist, $\mathrm{Ucn}_{\mathrm{c}}$, as well as sauvagine, a non selective $\mathrm{CRF}_{1} / \mathrm{CRF}_{2}$ agonist with higher affinity to $\mathrm{CRF}_{2}$, blunt repeated CRD- induced visceral sensitization. ${ }^{146,176}$ This indicates opposite effects of $\mathrm{CRF}_{1}$ and $\mathrm{CRF}_{2}$ signaling in the mechanosensitization of the colon. Similarly, $\mathrm{CRF}_{2}$ activation by in-

Table 1. Clinical Studies Showing Mimicry Between Activation of the Corticotropin-releasing Factor Signaling System and Irritable Bowel Syndrome-related Symptoms in Humans

\begin{tabular}{lc}
\hline $\begin{array}{l}\text { CRF agonists stimulate/activate/increase in } \\
\text { healthy humans or IBS patients }\end{array}$ & References \\
HPA axis & 21 \\
Colonic motility & 21 \\
Permeability/bacterial translocation & 184 \\
Viscerosensitivity & 178,179 \\
Mast cells & 184 \\
Anxiety/depression & 208 \\
Inflammation & 183 \\
CRF antagonists reverse IBS-associated increase of & \\
Anxiety + /- & 194 \\
Motility + /- & 21 \\
Permeability & 184 \\
Viscerosensitivity & 21 \\
\hline
\end{tabular}

CRF, corticotrophin-releasing factor; IBS, irritable bowel syndrome; HPA, hypothalamic-pituitary-adrenal. traperitoneally injected Ucn2 suppressed CRD- induced spinal phosphorylation of ERK 1/2 and visceral pain, although the exact site of $\mathrm{CRF}_{2}$ activation to inhibit spinal ERK $1 / 2$ activity is not known. ${ }^{176}$

\section{Corticotropin-releasing Factor Signaling in Healthy and Irritable Bowel Syndrome Subjects}

\section{Colonic Responses to Peripheral Corticotropin-releasing Factor Signaling}

The actions of peripheral CRF on the colon reported in experimental studies have been largely reproduced in healthy subjects or IBS patients along with preliminary evidence of the beneficial effect of peripheral injections of peptide CRF antagonist (Tables 1 and 2). With regards to the intestinal motility, one clinical report showed that systemic administration of CRF increases the motility index in the descending colon in both healthy and IBS groups with a significant higher response in the IBS groups. $^{177}$

Reports assessing changes in visceral pain established that systemic injection of the preferential $\mathrm{CRF}_{1}$ agonist, ovine $\mathrm{CRF}$ lowered pain thresholds to repetitive rectal distensions and enhanced the intensity of discomfort sensation to CRD in healthy humans. ${ }^{177-179}$ Beneficial effects of systemic injection of $\alpha$-helical $\mathrm{CRF}_{9-41}$ was reported in a setting of electrical rectal stimulation which evoked abdominal pain and anxiety in IBS patients compared with healthy subjects. ${ }^{180}$ There is also clinical evidence that systemic administration of the peptide antagonist normalizes the altered EEG activities in IBS patients under basal and in response to CRD. ${ }^{181}$

Table 2. Preclinical Studies Highlighting the Relevance of Corticotropin-releasing Factor Receptor 1 Blockade to Reduce Irritable Bowel Syndrome-like Symptoms (see reviews ${ }^{21,123,209,210}$ )

Clinical features of IBS-diarrhea predomient patients

Co-morbidity with anxiety and depression

Hypervigilance

Changes in autonomic functions ( $\downarrow$ vagal, $\uparrow$ sympathetic)

Increased bowel movements/diarrhea

Ion transport dysfunction

Change in mast cells (number, and activation)

Increase barrier permeability

Lower pain threshold to colorectal distention
$\mathrm{CRF}_{1}$ antagonists in experimental animals block stress-related

Anxiety/depression

CRD-induced locus coeruleus activation-induced hypervigilance

Autonomic responses ( $\downarrow$ vagal, $\uparrow$ sympathetic)

Increased colonic motility/defecation/diarrhea

Colonic mucosal barrier dysfunction

Activation of mast cells

Increase barrier permeability/antigen translocation

Hypersensitivity to colorectal distention

IBS, irritable bowel syndrome; $\mathrm{CRF}_{1}$, corticotrophin-releasing factor receptor 1; CRD, colorectal distention. 
Similar to rodent data, $\mathrm{CRF}$ receptors have been identified in human colonic biopsies and enteric nervous system. ${ }^{136,182,183} \mathrm{CRF}$ administered intravenously activates subepithelial mast cells, and stimulates transcellular uptake of protein antigens in colonic biopsies of healthy subjects. ${ }^{184}$ Since increased uptake of antigen-sized macromolecules is associated with inflammation, and there is increasing evidence that IBS patients display a low graded colonic inflammation, intraepithelial lymphocytes, mast cell degranulation and increased permeability, these changes may be consistent with enhanced colonic CRF signaling. ${ }^{185,186}$ Additionally, recent evidence showed the expression of $\mathrm{CRF}_{1}$ receptors and variants on human enterochromaffin-like cells, the BON subclone 1 cells. In these cells, $\mathrm{CRF}$ induces a $\mathrm{CRF}_{1}$ receptor mediated stimulation of 5-HT release and up regulated the expression of 5-HT synthesizing enzyme, tryptophan hydroxylase. ${ }^{36}$ Considering the important role of 5-HT in the pathophysiology of IBS, ${ }^{187}$ this may represents an additional site of action of CRF to increase colonic motility and visceral pain in human subjects.

\section{Does Targeting Corticotropin-releasing Factor Receptor Have Therapeutic Values?}

The vast amount of preclinical studies showing efficacy of $\mathrm{CRF}_{1}$ antagonists in various experimental IBS models raised high expectation regarding potential translational applications of $\mathrm{CRF}_{1}$ antagonists for therapeutic benefit in stress-sensitive human disorders. However, while a large number of small molecules $\mathrm{CRF}_{1}$ antagonists have been disclosed and used in a preclinical setting, ${ }^{59}$ only a few compounds have progressed to clinical trials. ${ }^{188}$ Indeed, many of these small molecule $\mathrm{CRF}_{1}$ antagonists encountered several set backs related to unattractive pharmacokinetics, prominent tissue accumulation due to lipophilicity, long elimination half-life, high protein binding, or reactive metabolite formation ${ }^{59,189}$ that precluded their clinical testing. Efforts are ongoing to overcome these issues as shown by recently disclosure of new compounds that are less lipophilic with improved pharmacokinetic properties due to the substitution of the propyl groups at the $\mathrm{C} 7$ position of the pyrazolol $[1,5 \alpha]$ pyrimidine core with heterocycles. ${ }^{33,189-192}$ The $\mathrm{CRF}_{1}$ antagonists which are or have reached clinical trials include CP-316311 (Pfizer), pexacerfont (Bristol-Myers Squibb), GSK-876008 and GS-561679 (GlaxoSmithKline), R317573 (Johnson \& Johnson), and few others, see review. ${ }^{58,59} \mathrm{CRF}_{1}$ antagonists such as NBI-30545 and NBI-35965 have the distinct advantage to be orally active and water soluble. ${ }^{58,59,80,192}$
Several clinical studies provided proof-of-concept that oral administration of $\mathrm{CRF}_{1}$ antagonists dampened stress-related biological responses in healthy human subjects. NBI-34041/ SB-723620 given at $100 \mathrm{mg} /$ day for 14 days reduced the Trier Social Stress Test and mental arithmetic test-induced rise in plasma levels of ACTH and cortisol in healthy male volunteers while not influencing basal circadian release of ACTH ${ }^{193}$ Further clinical testing, however, was not continued due to preclinical toxicology studies. In a clinical model of generalized anxiety induced by 20-min inhalation of $7.5 \% \mathrm{CO}_{2}$, preliminary studies in 12 healthy subjects showed that R317573 (40 mg once daily) given for 7 days significantly reduced panic symptom score and generalized anxiety compared to placebo. ${ }^{194}$ Positron emission tomography (PET) studies indicated that the acute administration of R317573 at 30 and $200 \mathrm{mg}$ results in dose-related changes in regional glucose metabolism in regions relevant to mood and anxiety disorders. ${ }^{195}$ A recent clinical study using functional magnetic resonance imaging showed that an acute oral administration of $\mathrm{CRF}_{1}$ antagonist, GW876008 (single dose of 20 or $200 \mathrm{mg}$ orally) dampened the amygdala activation produced by the anticipation of visceral pain compared to placebo drug in IBS female patients. ${ }^{196}$ Of note, $\mathrm{CRF}-\mathrm{CRF}_{1}$ signaling in the $\mathrm{CeA}$ is also well established to be a key component of the neuronal circuitry contributing to anxiety-like behavior ${ }^{197}$ and therefore well positioned to drive the reciprocal relationship between visceral pain and affective mood. ${ }^{198}$ This may provide the neuroanatomical and biochemical substrata to speculate that overactivity of the $\mathrm{CRF}_{-} \mathrm{CRF}_{1}$ in the CeA may underlie the comorbidity of subset of IBS patients who display hypersensitivity to $\mathrm{CRD}^{199}$ and mood disorders. $^{200}$

However, whether the existing or newly developed $\mathrm{CRF}_{1}$ antagonists ${ }^{59}$ will progress to show therapeutic benefits in subsets of IBS is still to be established. An early clinical trial in IBS-diarrhea predominant patients did not show beneficial effect of oral administration of the $\mathrm{CRF}_{1}$ antagonist paxacerfont (BMS562086) on IBS symptoms although a dose-related trend to reduce visceral pain was observed at $25 \mathrm{mg}$ and $100 \mathrm{mg}$ for 2 weeks. ${ }^{201}$ Several aspects may have been suboptimal including the dosing regimen as the $\mathrm{CRF}_{1}$ mediated $\mathrm{ACTH}$ levels were not monitored in this clinical trials. ${ }^{201}$ The lack of information on the central and peripheral occupancy of $\mathrm{CRF}_{1}$ antagonists in humans in the absence of PET ligand as well as the potential role of the more than 10 splice variants of the $\mathrm{CRF}_{1}$ receptor (some of which are functional) ${ }^{36,40}$ are additional factors. Efforts are undergoing to test radioligand for the $\mathrm{CRF}_{1}$ receptor to allow rational dose 
selection relying on large occupancy in the brain and colon. Importantly $\mathrm{CRF}_{1}$ antagonists may exert beneficial effects only under conditions of elevated brain/colonic $\mathrm{CRF} / \mathrm{CRF}_{1}$ signaling pathways that cannot be identified in the heterogeneous populations tested so far.

\section{Conclusion}

Both experimental and clinical studies in healthy subjects support that the activation of $\mathrm{CRF}_{1}$ pathways recaptures cardinal features of IBS-diarrhea symptoms (anxiogenic/hypervigilance behavior, colonic mast cell activation and serotonin release, stimulation of colonic propulsive motor function and watery diarrhea, and visceral hyperalgesia) (Table 1). Another key preclinical evidence arises from pharmacological interventions whereby blockade of brain or peripheral $\mathrm{CRF}_{1}$ receptors prevent/blunt the development of the above CRF or stress-related functional or cellular alterations. ${ }^{123,202}$ Selective $\mathrm{CRF}_{1}$ antagonists or $\mathrm{CRF}_{1} / \mathrm{CRF}_{2}$ antagonists abolished or reduced exogenous $\mathrm{CRF}$ and stress-induced anxiogenic/depressive behavior, stimulation of colonic motility, mucus secretion, mast cell activation, defecation, diarrhea, and pain related to colonic hyperalgesia (Table 2). Therefore, the conceptual framework supports that sustained activation of the $\mathrm{CRF}_{1}$ system at central and/or peripheral sites may be one component underlying IBS symptoms. Targeting these mechanisms by $\mathrm{CRF}_{1}$ antagonists provided a relevant novel therapeutic venue. However so far these promising preclinical data have not translated yet into therapeutic use of $\mathrm{CRF}_{1}$ antagonists. Therefore, whether the existing or newly developed $\mathrm{CRF}_{1}$ antagonists will progress to therapeutic benefits for stress-sensitive diseases including IBS for a subset of patients is still a work in progress. Of note is also the inhibitory effects of $\mathrm{CRF}_{2}$ receptor activation on stress-related gut motility and sensitization, as a gut stress coping system and the possible $\mathrm{CRF}_{1}-\mathrm{CRF}_{2}$ cross talk in the co$\operatorname{lon}^{54,176,203}$ and the brain ${ }^{204}$ that need to be taken into consideration in targeting CRF signaling for gut centric intestinal secretomotor alterations and visceral pain therapeutic purposes. CRF being pivotal in the body's response to stressful stimuli and the extensive preclinical data indicating that dysregulation of $\mathrm{CRF}_{-} \mathrm{CRF}_{1}$ system is implicated in the etiology and maintenance of several stress-sensitive disorders as recently reviewed, ${ }^{20,205-207}$ a better understanding of CRF signaling is likely to provide novel insights in the otherwise challenging pathophysiology of functional gut diseases such as IBS.

\section{References}

1. Cabanis PJG. Introduction: On the relations between the physical and moral aspects of man. In: Mora G, Saidi MD, eds. Baltimore: Johns Hopkins University Press 1981:650.

2. Beaumont W. In: Osler W, ed. Experiments and observations on the gastric juice and the physiology of digestion. New York: Dover Publications Inc 1833.

3. Fukudo S, Kanazawa M. Gene, environment, and brain-gut interactions in irritable bowel syndrome. J Gastroenterol Hepatol 2011; 26(suppl 3):110-115.

4. Jones MP, Dilley JB, Drossman D, Crowell MD. Brain-gut connections in functional GI disorders: anatomic and physiologic relationships. Neurogastroenterol Motil 2006;18:91-103.

5. Taché Y. Central nervous system action of neuropeptides to induce or prevent experimental gastroduodenal ulcerations. Perspect Behav Med 1988;5:101-112.

6. Aziz Q, Thompson DG. Brain-gut axis in health and disease. Gastroenterology 1998;114:559-578.

7. Al Omran Y, Aziz Q. The brain-gut axis in health and disease. Adv Exp Med Biol 2014;817:135-153.

8. Konturek SJ, Konturek JW, Pawlik T, Brzozowski T. Brain-gut axis and its role in the control of food intake. J Physiol Pharmacol 2004;55(1 Pt 2):137-154.

9. Stasi C, Orlandelli E. Role of the brain-gut axis in the pathophysiology of Crohn's disease. Dig Dis 2008;26:156-166.

10. Koloski NA, Jones M, Kalantar J, Weltman M, Zaguirre J, Talley NJ. The brain - gut pathway in functional gastrointestinal disorders is bidirectional: a 12-year prospective population-based study. Gut 2012;61:1284-1290.

11. Coss-Adame E, Rao SS. Brain and gut interactions in irritable bowel syndrome: new paradigms and new understandings. Curr Gastroenterol Rep 2014;16:379.

12. Taché $\mathrm{Y}$, Bernstein $\mathrm{CN}$. Evidence for the role of the brain-gut axis in inflammatory bowel disease: depression as cause and effect? Gastroenterology 2009;136:2058-2061.

13. Slyepchenko A, Carvalho AF, Cha DS, Kasper S, McIntyre RS. Gut emotions - mechanisms of action of probiotics as novel therapeutic targets for depression and anxiety disorders. CNS Neurol Disord Drug Targets Published Online First: 30 Nov 2014.

14. Taché Y. The parasympathetic nervous system in the pathophysiology of the gastrointestinal tract. In: Bolis CL., Licinio J, Govoni S, eds. Handbook of autonomic nervous system in health and disease. New York: Dekker Inc 2002:464-503.

15. Lomax AE, Sharkey KA, Furness JB. The participation of the sympathetic innervation of the gastrointestinal tract in disease states. Neurogastroenterol Motil 2010;22:7-18.

16. Grundy D. Neuroanatomy of visceral nociception: vagal and splanchnic afferent. Gut 2002;51(suppl 1):i2-i5.

17. Filaretova L. The hypothalamic-pituitary-adrenocortical system: hormonal brain-gut interaction and gastroprotection. Auton Neurosci 2006;125:86-93.

18. Holzer P, Farzi A. Neuropeptides and the microbiota-gut-brain axis. Adv Exp Med Biol 2014;817:195-219. 
19. Stengel A, Taché Y. Corticotropin-releasing factor signaling and visceral response to stress. Exp Biol Med (Maywood) 2010;235: 1168-1178.

20. Taché Y, Brunnhuber S. From Hans Selye's discovery of biological stress to the identification of corticotropin-releasing factor signaling pathways: implication in stress-related functional bowel diseases. Ann N Y Acad Sci 2008;1148:29-41.

21. Fukudo $\mathrm{S}$. Role of corticotropin-releasing hormone in irritable bowel syndrome and intestinal inflammation. J Gastroenterol 2007; 42(suppl 17):48-51.

22. Vale W, Vaughan J, Perrin M. Corticotropin-releasing factor (CRF) family of ligands and their receptors. The Endocrinologist 1997;7: S3-S9.

23. Vale W, Spiess J, Rivier C, Rivier J. Characterization of a 41- residue ovine hypothalamic peptide that stimulates secretion of corticotropin and b-endorphin. Science 1981;213:1394-1397.

24. Lovejoy DA, Balment RJ. Evolution and physiology of the corticotropin-releasing factor (CRF) family of neuropeptides in vertebrates. Gen Comp Endocrinol 1999;115:1-22.

25. Vaughan J, Donaldson C, Bittencourt J, et al. Urocortin, a mammalian neuropeptide related to fish urotensin I and to corticotropin-releasing factor. Nature 1995;378:287-292.

26. Hsu SY, Hsueh AJ. Human stresscopin and stresscopin-related peptide are selective ligands for the type 2 corticotropin-releasing hormone receptor. Nat Med 2001;7:605-611.

27. Lewis $\mathrm{K}, \mathrm{Li} \mathrm{C}$, Perrin MH, et al. Identification of urocortin III, an additional member of the corticotropin-releasing factor (CRF) family with high affinity for the CRF2 receptor. Proc Natl Acad Sci USA 2001;98:7570-7575.

28. Hauger RL, Grigoriadis DE, Dallman MF, Plotsky PM, Vale WW, Dautzenberg FM. International Union of Pharmacology. XXXVI. Current status of the nomenclature for receptors for corticotropin-releasing factor and their ligands. Pharmacol Rev 2003; $55: 21-26$.

29. Reyes TM, Lewis K, Perrin MH, et al. Urocortin II: A member of the corticotropin-releasing factor (CRF) neuropeptide family that is selectively bound by type 2 CRF receptors. Proc Natl Acad Sci USA 2001;98:2843-2848.

30. Chalmers DT, Lovenberg TW, Grigoriadis DE, Behan DP, De Souza EB. Corticotropin-releasing factor receptors: from molecular biology to drug design. Trends Pharmacol Sci 1996;17:166-172.

31. Perrin $\mathrm{MH}$, Vale WW. Corticotropin releasing factor receptors and their ligand family. Ann N Y Acad Sci 1999;885:312-328.

32. Chalmers DT, Lovenberg TW, De Souza EB. Localization of novel corticotropin-releasing factor receptor $\left(\mathrm{CRF}_{2}\right) \mathrm{mRNA}$ expression to specific subcortical nuclei in rat brain: comparison with CRF1 receptor mRNA expression. J Neurosci 1995;15:6340-6350.

33. Liapakis G, Venihaki M, Margioris A, Grigoriadis D, Gkountelias K. Members of CRF family and their receptors: from past to future. Curr Med Chem 2011;18:2583-2600.

34. Hillhouse EW, Grammatopoulos DK. The molecular mechanisms underlying the regulation of the biological activity of corticotropin-releasing hormone receptors: implications for physiology and pathophysiology. Endocr Rev 2006;27:260-286.

35. Karteris E, Markovic D, Chen J, Hillhouse EW, Grammatopoulos DK. Identification of a novel corticotropin-releasing hormone type
$1 \beta$-like teceptor variant lacking exon 13 in human pregnant myometrium regulated by estradiol-17 $\beta$ and progesterone. Endocrinology 2010;151:4959-4968.

36. Wu SV, Yuan PQ, Lai J, et al. Activation of Type 1 CRH receptor isoforms induces serotonin release from human carcinoid BON-1N cells: an enterochromaffin cell model. Endocrinology 2011;152: 126-137.

37. Zmijewski MA, Slominski AT. Emerging role of alternative splicing of $\mathrm{CRF}_{1}$ receptor in $\mathrm{CRF}$ signaling. Acta Biochim Pol 2010; 57:1-13.

38. Wu SV, Yuan PQ, Wang L, Peng YL, Chen CY, Taché Y. Identification and characterization of multiple corticotropin- releasing factor type 2 receptor isoforms in the rat esophagus. Endocrinology 2007;148:1675-1687.

39. Yuan PQ, Wu SV, Taché Y. Urocortins and CRF type 2 receptor isoforms expression in the rat stomach are regulated by endotoxin: role in the modulation of delayed gastric emptying. Am J Physiol Gastrointest Liver Physiol 2012;303:G20-G31.

40. Zmijewski MA, Slominski AT. CRF1 receptor splicing in epidermal keratinocytes: potential biological role and environmental regulations. J Cell Physiol 2009;218:593-602.

41. Chen AM, Perrin MH, Digruccio MR, et al. A soluble mouse brain splice variant of type $2 \alpha$ corticotropin-releasing factor (CRF) receptor binds ligands and modulates their activity. Proc Natl Acad Sci USA 2005;102:2620-2625.

42. Markovic D, Vatish M, Gu M, et al. The onset of labor alters corticotropin-releasing hormone type 1 receptor variant expression in human myometrium: putative role of interleukin-1beta. Endocrinology 2007;148:3205-3213.

43. Dautzenberg FM, Hauger RL. The CRF peptide family and their receptors: yet more partners discovered. Trends Pharmacol Sci 2002;23:71-77.

44. Tezval H, Jahn O, Todorovic C, Sasse A, Eckart K, Spiess J. Cortagine, a specific agonist of corticotropin-releasing factor receptor subtype 1 , is anxiogenic and antidepressive in the mouse model. Proc Natl Acad Sci USA 2004;101:9468-9473.

45. Rivier J, Gulyas J, Kunitake K, et al. Stressin ${ }_{1}-\mathrm{A}$, a potent corticotropin releasing factor receptor $1\left(\mathrm{CRF}_{1}\right)$-selective peptide agonist. J Med Chem 2007;50:1668-1674.

46. Grammatopoulos DK. Insights into mechanisms of corticotropinreleasing hormone receptor signal transduction. Br J Pharmacol 2012;166:85-97.

47. Pal K, Swaminathan K, Xu HE, Pioszak AA. Structural basis for hormone recognition by the Human CRFR2 $\alpha$ G protein-coupled receptor. J Biol Chem 2010;285:40351-40361.

48. Ardati A, Goetschy V, Gottowick J, et al. Human $\mathrm{CRF}_{2}$ a and b splice variants: pharmacological characterization using radioligand binding and a luciferase gene expression assay. Neuropharmacology 1999;38:441-448.

49. Kostich WA, Chen A, Sperle K, Largent BL. Molecular identification and analysis of a novel human corticotropin-releasing factor (CRF) receptor: the CRF2ÿ receptor. Mol Endocrinol 1998;12: 1077-1085.

50. Suman-Chauhan N, Carnell P, Franks R, et al. Expression and characterisation of human and rat CRF2alpha receptors. Eur J Pharmacol 1999;379:219-227. 
51. Miyata I, Shiota C, Ikeda Y, et al. Cloning and characterization of a short variant of the corticotropin-releasing factor receptor subtype from rat amygdala. Biochem Biophys Res Commun 1999;256:692696

52. Grigoriadis DE, Hoare SR, Lechner SM, Slee DH, Williams JA. Drugability of extracellular targets: discovery of small molecule drugs targeting allosteric, functional, and subunit-selective sites on GPCRs and ion channels. Neuropsychopharmacology 2009;34: 106-125.

53. Berger H, Heinrich N, Wietfeld D, Bienert M, Beyermann M. Evidence that corticotropin-releasing factor receptor type 1 couples to Gs- and Gi-proteins through different conformations of its J-domain. Br J Pharmacol 2006;149:942-947.

54. Gourcerol G, Wu SV, Yuan PQ, et al. Activation of corticotropin-releasing factor receptor 2 mediates the colonic motor coping response to acute stress in rodents. Gastroenterology 2011;140: 1586-1596, e6.

55. Moss AC, Anton P, Savidge T, Newman P, Cheifetz AS, Gay J et al. Urocortin II mediates pro-inflammatory effects in human colonocytes via corticotropin-releasing hormone receptor 2alpha. Gut 2007;56:1210-1217.

56. Rivier JE, Rivier CL. Corticotropin-releasing factor peptide antagonists: design, characterization and potential clinical relevance. Front Neuroendocrinol 2014;35:161-170.

57. Yamada Y, Mizutani K, Mizusawa Y, Hantani Y, Tanaka M, Tanaka $\mathrm{Y}$ et al. New class of corticotropin-releasing factor (CRF) antagonists: small peptides having high binding affinity for CRF receptor. J Med Chem 2004;47:1075-1078.

58. Kehne JH, Cain CK. Therapeutic utility of non-peptidic $\mathrm{CRF}_{1}$ receptor antagonists in anxiety, depression, and stress-related disorders: evidence from animal models. Pharmacol Ther 2010;128: 460-487.

59. Zorrilla EP, Koob GF. Progress in corticotropin-releasing factor-1 antagonist development. Drug Discov Today 2010;15:371-383.

60. Turnbull AV, Rivier C. Corticotropin-releasing factor (CRF) and endocrine response to stress: $\mathrm{CRF}$ receptors, binding protein, and related peptides. Proc Soc Exp Biol Med 1997;215:1-10.

61. Taché Y, Bonaz B. Corticotropin-releasing factor receptors and stress-related alterations of gut motor function. J Clin Invest 2007; 117:33-40.

62. Gilligan PJ. Corticotropin-releasing factor receptor antagonists. Expert Opin Ther Pat 2006;16:913-924.

63. Kastin AJ, Akerstrom V. Differential interactions of urocortin/corticotropin-releasing hormone peptides with the blood-brain barrier. Neuroendocrinology 2002;75:367-374.

64. Martinez V, Rivier J, Taché Y. Peripheral injection of a new corticotropin-releasing factor (CRF) antagonist, astressin, blocks peripheral CRF-and abdominal surgery-induced delayed gastric emptying in rats. J Pharmacol Exp Ther 1999;290:629-634.

65. Drüge G1, Raedler A, Greten H, Lenz HJ. Pathways mediating CRF-induced inhibition of gastric acid secretion in rats. Am J Physiol 1989;256(1 Pt 1):G214-G219.

66. Zorrilla EP, Koob GF. The therapeutic potential of $\mathrm{CRF}_{1}$ antagonists for anxiety. Expert Opin Investig Drugs 2004;13:799-828.

67. Charlton BG, Ferrier IN, Perry RH. Distribution of corticotropin-releasing factor-like immunoreactivity in human brain.
Neuropeptides 1987;10:329-334.

68. Wang L, Goebel-Stengel M, Stengel A, Wu SV, Ohning G, Taché $\mathrm{Y}$. Comparison of CRF-immunoreactive neurons distribution in mouse and rat brains and selective induction of Fos in rat hypothalamic CRF neurons by abdominal surgery. Brain Res 2011; 1415:34-46.

69. Justice NJ, Yuan ZF, Sawchenko PE, Vale W. Type 1 corticotropin-releasing factor receptor expression reported in BAC transgenic mice: implications for reconciling ligand-receptor mismatch in the central corticotropin-releasing factor system. J Comp Neurol 2008;511:479-496.

70. Bonaz B, Rivest S. Effect of a chronic stress on CRF neuronal activity and expression of its type 1 receptor in the rat brain. Am J Physiol 1998;275(5 Pt 2):R1438-R1449.

71. Imaki T, Katsumata H, Miyata M, Naruse M, Imaki J, Minami S. Expression of corticotropin-releasing hormone type 1 receptor in paraventricular nucleus after acute stress. Neuroendocrinology 2001;73:293-301.

72. Williams CL, Peterson JM, Villar RG, Burks TF. Corticotropinreleasing factor directly mediates colonic responses to stress. Am J Physiol 1987;253(4 Pt 1):G582-G586.

73. Lenz HJ, Burlage M, Raedler A, Greten H. Central nervous system effects of corticotropin-releasing factor on gastrointestinal transit in the rat. Gastroenterology 1988;94:598-602.

74. Martinez V, Wang L, Rivier J, Grigoriadis D, Taché Y. Central $\mathrm{CRF}$, urocortins and stress increase colonic transit via $\mathrm{CRF}_{1}$ receptors while activation of CRF2 receptors delays gastric transit in mice. J Physiol 2004;556(Pt 1):221-234.

75. Martinez V, Rivier J, Wang L, Taché Y. Central injection of a new corticotropin-releasing factor (CRF) antagonist, astressin, blocks CRF- and stress-related alterations of gastric and colonic motor function. J Pharmacol Exp Ther 1997;280:754-760.

76. Miyata $\mathrm{K}$, Ito $\mathrm{H}$, Fukudo S. Involvement of the $5-\mathrm{HT}_{3}$ receptor in CRH-induce defecation in rats. Am J Physiol 1998;274(5 Pt 1):G827-G831.

77. Jiménez M, Buéno L. Inhibitory effects of neuropeptide Y (NPY) on CRF and stress-induced cecal motor response in rats. Life Sci 1990;47:205-211.

78. Hirata T, Keto Y, Nakata M, et al. Effects of serotonin 5-HT 3 receptor antagonists on CRF-induced abnormal colonic water transport and defecation in rats. Eur J Pharmacol 2008;587:281-284.

79. Park AJ, Collins J, Blennerhassett PA, et al. Altered colonic function and microbiota profile in a mouse model of chronic depression. Neurogastroenterol Motil 2013;25:733-e575.

80. Million M, Zhao JF, Luckey A, et al. The newly developed $\mathrm{CRF}_{1}$ receptor antagonists, NGD 98-2 and NGD 9002, suppress acute stress-induced stimulation of colonic motor function and visceral hypersensitivity in rats. PLoS One 2013;8:e73749.

81. Bonaz B, Taché Y. Water-avoidance stress-induced c-fos expression in the rat brain and stimulation of fecal output: role of corticotropin-releasing factor. Brain Res 1994;641:21-28.

82. Gué M, Junien JL, Buéno L. Conditioned emotional response in rats enhances colonic motility through the central release of corticotropin-releasing factor. Gastroenterology 1991;100:964-970.

83. Lenz HJ, Raedler A, Greten H, Vale WW, Rivier JE. Stress-induced gastrointestinal secretory and motor responses in rats are 
mediated by endogenous corticotropin-releasing factor. Gastroenterology 1988;95:1510-1517.

84. Martinez $\mathrm{V}$, Taché $\mathrm{Y}$. Role of $\mathrm{CRF}$ receptor 1 in central CRF-induced stimulation of colonic propulsion in rats. Brain Res 2001; 893:29-35.

85. Million M, Wang L, Martinez V, Taché Y. Differential Fos expression in the paraventricular nucleus of the hypothalamus, sacral parasympathetic nucleus and colonic motor response to water avoidance stress in Fischer and Lewis rats. Brain Res 2000;877:345-353.

86. Funatsu T, Takeuchi A, Hirata T, Keto Y, Akuzawa S, Sasamata M. Effect of ramosetron on conditioned emotional stress-induced colonic dysfunction as a model of irritable bowel syndrome in rats. Eur J Pharmacol 2007;573:190-195.

87. Gabry KE, Chrousos GP, Rice KC, et al. Marked suppression of gastric ulcerogenesis and intestinal responses to stress by a novel class of drugs. Mol Psychiatry 2002;7:474-483.

88. Ataka K, Kuge T, Fujino K, Takahashi T, Fujimiya M. Wood creosote prevents $\mathrm{CRF}$-induced motility via 5 -HT3 receptors in proximal and 5-HT4 receptors in distal colon in rats. Auton Neurosci 2007;133:136-145.

89. Yoshimoto S, Cerjak D, Babygirija R, Bulbul M, Ludwig K, Takahashi T. Hypothalamic circuit regulating colonic transit following chronic stress in rats. Stress 2012;15:227-236.

90. Saito K, Kasai T, Nagura Y, Ito H, Kanazawa M, Fukudo S. Corticotropin-releasing hormone receptor 1 antagonist blocks brain-gut activation induced by colonic distention in rats. Gastroenterology 2005;129:1533-1543.

91. Bale TL, Picetti R, Contarino A, Koob GF, Vale WW, Lee KF. Mice deficient for both corticotropin-releasing factor receptor 1 (CRFR1) and CRFR2 have an impaired stress response and display sexually dichotomous anxiety-like behavior. J Neurosci 2002;22: 193-199.

92. Taché Y, Martinez V, Wang L, Million M. $\mathrm{CRF}_{1}$ receptor signaling pathways are involved in stress-related alterations of colonic function and viscerosensitivity: implications for irritable bowel syndrome. Br J Pharmacol 2004;141:1321-1330.

93. Mönnikes H, Schmidt BG, Tebbe J, Bauer C, Taché Y. Microinfusion of corticotropin releasing factor into the locus coeruleus/subcoeruleus stimulates colonic motor function in rats. Brain Res 1994;644:101-108.

94. Mönnikes H, Raybould HE, Schmidt B, Taché Y. CRF in the paraventricular nucleus of the hypothalamus stimulates colonic motor activity in fasted rats. Peptides 1993;14:743-747.

95. Mönnikes H, Schmidt BG, Raybould HE, Taché Y. CRF in the paraventricular nucleus mediates gastric and colonic motor response to restraint stress. Am J Physiol 1992;262(1 Pt 1):G137-G143.

96. Mönnikes H, Schmidt BG, Taché Y. Psychological stress-induced accelerated colonic transit in rats involves hypothalamic corticotropin-releasing factor. Gastroenterology 1993;104:716-723.

97. Mönnikes H, Heymann-Monnikes I, Taché Y. CRF in the paraventricular nucleus of the hypothalamus induces dose-related behavioral profile in rats. Brain Res 1992;574:70-76.

98. Weiss JM, Stout JC, Aaron MF, et al. Depression and anxiety: role of the locus coeruleus and corticotropin-releasing factor. Brain Res Bull 1994;35:561-572.

99. Rouzade-Dominguez ML, Pernar L, Beck S, Valentino RJ.
Convergent responses of Barrington's nucleus neurons to pelvic visceral stimuli in the rat: a juxtacellular labelling study. Eur J Neurosci 2003;18:3325-3334.

100. Sawchenko PE, Swanson LW. Immunohistochemical identification of neurons in the paraventricular nucleus of the hypothalamus that project to the medulla or the spinal cord in the rat. J Comp Neurol 1982;205:260-272.

101. Tebbe JJ, Mronga S, Tebbe CG, Ortmann E, Arnold R, Schäfer MK. Ghrelin-induced stimulation of colonic propulsion is dependent on hypothalamic neuropeptide Y1- and corticotrophin-releasing factor 1 receptor activation. J Neuroendocrinol 2005;17:570-576.

102. Mönnikes H, Tebbe J, Bauer C, Grote C, Arnold R. Neuropeptide $\mathrm{Y}$ in the paraventricular nucleus of the hypothalamus stimulates colonic transit by peripheral cholinergic and central CRF pathways. Neurogastroenterol Motil 2000;12:343-352.

103. Tebbe JJ, Pasat IR, Mönnikes H, Ritter M, Kobelt P, Schäfer MK. Excitatory stimulation of neurons in the arcuate nucleus intitiates central CRF-dependent stimulation of colonic propulsion in rats. Brain Res 2005;1036:130-138.

104. Tebbe JJ, Ortmann E, Schumacher K, et al. Cocaine- and amphetamine-regulated transcript stimulates colonic motility via central CRF receptor activation and peripheral cholinergic pathways in fed, conscious rats. Neurogastroenterol Motil 2004;16:489-496.

105. Junien JL, Gue M, Bueno L. Neuropeptide $Y$ and sigma ligand (JO 1784) act through a Gi protein to block the psychological stress and corticotropin-releasing factor-induced colonic motor activation in rats. Neuropharmacology 1991;30:1119-1124.

106. Nakade Y, Tsukamoto K, Iwa M, Pappas TN, Takahashi T. Glucagon like peptide-1 accelerates colonic transit via central CRF and peripheral vagal pathways in conscious rats. Auton Neurosci 2007;131:50-56.

107. Nakade Y, Fukuda H, Iwa M, et al. Restraint stress stimulates colonic motility via central corticotropin-releasing factor and peripheral 5- $\mathrm{HT}_{3}$ receptors in conscious rats. Am J Physiol Gastrointest Liver Physiol 2007;292:G1037-G1044.

108. Martinez V, Wang L, Rivier JE, Vale W, Taché Y. Differential actions of peripheral corticotropin-releasing factor $(\mathrm{CRF})$, urocortin II, and urocortin III on gastric emptying and colonic transit in mice: role of CRF receptor subtypes 1 and 2. J Pharmacol Exp Ther 2002;301:611-617.

109. Tsukamoto K, Nakade Y, Mantyh C, Ludwig K, Pappas TN, Takahashi T. Peripherally administered CRF stimulates colonic motility via central CRF receptors and vagal pathways in conscious rats. Am J Physiol Regul Integr Comp Physiol 2006;290:R1537R1541.

110. Maillot C, Million M, Wei JY, Gauthier A, Taché Y. Peripheral corticotropin-releasing factor and stress-stimulated colonic motor activity involve type 1 receptor in rats. Gastroenterology 2000;119: 1569-1579.

111. Million M, Maillot C, Saunders PR, Rivier J, Vale W, Taché Y. Human urocortin II, a new CRF-related peptide, displays selective $\mathrm{CRF}_{2}$-mediated action on gastric transit in rats. Am J Physiol Gastrointest Liver Physiol 2002;282:G34-G40.

112. Saunders PR, Maillot C, Million M, Taché Y. Peripheral corticotropin-releasing factor induces diarrhea in rats: role of $\mathrm{CRF}_{1}$ receptor in fecal watery excretion. Eur J Pharmacol 2002;435:231- 
235

113. Castagliuolo I, Lamont JT, Qiu B, et al. Acute stress causes mucin release from rat colon: role of corticotropin releasing factor and mast cells. Am J Physiol 1996;271(5 Pt 1):G884-G892.

114. Maillot C, Wang L, Million M, Taché Y. Intraperitoneal corticotropin-releasing factor and urocortin induce Fos expression in brain and spinal autonomic nuclei and long lasting stimulation of colonic motility in rats. Brain Res 2003;974:70-81.

115. Gourcerol G, Wang L, Adelson DW, Larauche M, Taché Y, Million M. Cholinergic giant migrating contractions in conscious mouse colon assessed by using a novel noninvasive solid-state manometry method: modulation by stressors. Am J Physiol Gastrointest Liver Physiol 2009;296:G992-G1002.

116. Yuan PQ, Million M, Wu SV, Rivier J, Taché Y. Peripheral corticotropin releasing factor $(\mathrm{CRF})$ and a novel CRF1 receptor agonist, stressin $_{1}-\mathrm{A}$ activate CRF1 receptor expressing cholinergic and nitrergic myenteric neurons selectively in the colon of conscious rats. Neurogastroenterol Motil 2007;19:923-936.

117. Larauche M, Gourcerol G, Wang L, et al. Cortagine, a CRF1 agonist, induces stresslike alterations of colonic function and visceral hypersensitivity in rodents primarily through peripheral pathways. Am J Physiol Gastrointest Liver Physiol 2009;297:G215-G227.

118. Yuan PQ, Wu SV, Wang L, Taché Y. Corticotropin releasing factor in the rat colon: expression, localization and upregulation by endotoxin. Peptides 2010;31:322-331.

119. o'malley D, Dinan TG, Cryan JF. Alterations in colonic corticotropin-releasing factor receptors in the maternally separated rat model of irritable bowel syndrome: differential effects of acute psychological and physical stressors. Peptides 2010;31:662-670.

120. Chatzaki E, Crowe PD, Wang L, Million M, Taché Y, Grigoriadis D. CRF receptor type 1 and 2 expression and anatomical distribution in the rat colon. J Neurochem 2004;90:309-316.

121. O'malley D, Julio-Pieper M, Gibney SM, Gosselin RD, Dinan TG, Cryan JF. Differential stress-induced alterations of colonic corticotropin-releasing factor receptors in the Wistar Kyoto rat. Neurogastroenterol Motil 2010;22:301-311.

122. Kimura T, Amano T, Uehara $\mathrm{H}$, et al. Urocortin $\mathrm{I}$ is present in the enteric nervous system and exerts an excitatory effect via cholinergic and serotonergic pathways in the rat colon. Am J Physiol Gastrointest Liver Physiol 2007;293:G903-G910.

123. Larauche M, Kiank C, Taché Y. Corticotropin releasing factor signaling in colon and ileum: regulation by stress and pathophysiological implications. J Physiol Pharmacol 2009;60(suppl 7):33-46.

124. Mancinelli R, Azzena GB, Diana M, Forgione A, Fratta W. In vitro excitatory actions of corticotropin-releasing factor on rat colonic motility. J Auton Pharmacol 1998;18:319-324.

125. Liu S, Gao X, Gao N, et al. Expression of type 1 corticotropin-releasing factor receptor in the guinea pig enteric nervous system. $\mathrm{J}$ Comp Neurol 2005;481:284-298.

126. Dragunow M, Faull R. The use of c-fos as a metabolic marker in neuronal pathways tracing. J Neurosci Methods 1989;29:261-265.

127. Miampamba M, Maillot C, Million M, Taché Y. Peripheral CRF activates myenteric neurons in the proximal colon through $\mathrm{CRF}_{1}$ receptor in conscious rats. Am J Physiol Gastrointest Liver Physiol 2002;282:G857-G865.

128. Miampamba M, Million M, Yuan PQ, Larouche M, Taché Y.
Water avoidance stress activates colonic myenteric neurons in female rats. Neuroreport 2007;18:679-682.

129. Hanani M, Wood JD. Corticotropin-releasing hormone excites myenteric neurons in the guinea-pig small intestin. Eur J Pharmacol 1992;211:23-27.

130. Liu S, Ren W, Qu MH, et al. Differential actions of urocortins on neurons of the myenteric division of the enteric nervous system in guinea pig distal colon. Br J Pharmacol 2010;159:222-236.

131. O’Malleya D, Cryana JF, Dinana TG. Crosstalk between interleukin-6 and corticotropin-releasing factor modulate submucosal plexus activity and colonic secretion. Brain Behav Immun 2013;30: 115-124.

132. Chang J, Hoy JJ, Idumalla PS, Clifton MS, Pecoraro NC, Bhargava A. Urocortin 2 expression in the rat gastrointestinal tract under basal conditions and in chemical colitis. Peptides 2007;28: 1453-1460.

133. Chatzaki E, Anton PA, Million M, et al. Corticotropin-releasing factor receptor subtype 2 in human colonic mucosa: down-regulation in ulcerative colitis. World J Gastroenterol 2013;19:14161423.

134. Saruta M, Takahashi K, Suzuki T, Fukuda T, Torii A, Sasano H. Urocortin 3/stresscopin in human colon: possible modulators of gastrointestinal function during stressful conditions. Peptides $2005 ; 26$ : 1196-1206.

135. Muramatsu Y, Fukushima K, Iino K, et al. Urocortin and corticotropin-releasing factor receptor expression in the human colonic mucosa. Peptides 2000;21:1799-1809.

136. Wallon C, Söderholm JD. Corticotropin-releasing hormone and mast cells in the regulation of mucosal barrier function in the human colon. Ann N Y Acad Sci 2009;1165:206-210.

137. Million M, Wang L, Stenzel-Poore MP, et al. Enhanced pelvic responses to stressors in female CRF-overexpressing mice. Am J Physiol Regul Integr Comp Physiol 2006;.292:R1429-R1438.

138. Smith F, Clark JE, Overman BL, et al. Early weaning stress impairs development of mucosal barrier function in the porcine intestine. Am J Physiol Gastrointest Liver Physiol 2010;298:G352-G363.

139. Gué M, Del Rio-Lacheze C, Eutamene H, Théodorou V, Fioramonti J, Buéno L. Stress-induced visceral hypersensitivity to rectal distension in rats: role of $\mathrm{CRF}$ and mast cells. Neurogastroenterol Motil 1997;9:271-279.

140. Greenwood-Van Meerveld B, Johnson AC, Cochrane S, Schulkin J, Myers DA. Corticotropin-releasing factor 1 receptor-mediated mechanisms inhibit colonic hypersensitivity in rats. Neurogastroenterol Motil 2005;17:415-422.

141. Million M, Grigoriadis DE, Sullivan S, et al. A novel water-soluble selective $\mathrm{CRF}_{1}$ receptor antagonist, NBI 35965, blunts stress-induced visceral hyperalgesia and colonic motor function in rats. Brain Res 2003;985:32-42.

142. Schwetz I, Bradesi S, McRoberts JA, et al. Delayed stress-induced colonic hypoersensitivity in male Wistar rats: role of neurokinin-1 and corticotropin releasing factor-1 receptors. Am J Physiol Gastrointest Liver Physiol 2004;286:G683-G691.

143. Schwetz I, McRoberts JA, Coutinho SV, et al. Corticotropin-releasing factor receptor 1 mediates acute and delayed stress-induced visceral hyperalgesia in maternally separated Long-Evans rats. Am J Physiol Gastrointest Liver Physiol 2005;289:G704-G712. 
144. Larauche M, Bradesi S, Million M, et al. Corticotropin-releasing factor type 1 receptors mediate the visceral hyperalgesia induced by repeated psychological stress in rats. Am J Physiol Gastrointest Liver Physiol 2008;294:G1033-G1040.

145. Saito-Nakaya K, Hasegawa R, Nagura Y, Ito H, Fukudo S. Corticotropin-releasing hormone receptor 1 antagonist blocks colonic hypersensitivity induced by a combination of inflammation and repetitive colorectal distension. Neurogastroenterol Motil 2008;20: 1147-1156.

146. Million M, Maillot C, Adelson DW, et al. Peripheral injection of sauvagine prevents repeated colorectal distention-induced visceral pain in female rats. Peptides 2005;26:1188-1195.

147. Buckley MM, O'Halloran KD, Rae MG, Dinan TG, o'malley D. Modulation of enteric neurons by interleukin- 6 and corticotropin-releasing factor contributes to visceral hypersensitivity and altered colonic motility in a rat model of irritable bowel syndrome. J Physiol 2014;592(Pt 23):5235-5250.

148. Smith C, Nordstrom E, Sengupta JN, Miranda A. Neonatal gastric suctioning results in chronic visceral and somatic hyperalgesia: role of corticotropin releasing factor. Neurogastroenterol Motil 2007;19: 692-699.

149. Trimble N, Johnson AC, Foster A, Greenwood-Van Meerveld B. Corticotropin-releasing factor receptor 1-deficient mice show decreased anxiety and colonic sensitivity. Neurogastroenterol Motil 2007;19:754-760.

150. Bradesi S, Martinez V, Lao L, Larsson H, Mayer EA. Involvement of vasopressin 3 receptors in chronic psychological stress-induced visceral hyperalgesia in rats. Am J Physiol Gastrointest Liver Physiol 2009;296:G302-G309.

151. Jia FY, Li XL, Li TN, Wu J, Xie BY, Lin L. Role of nesfatin-1 in a rat model of visceral hypersensitivity. World J Gastroenterol 2013;19:3487-3493.

152. Tran L, Schulkin J, Greenwood-Van Meerveld B. Importance of $\mathrm{CRF}$ receptor-mediated mechanisms of the bed nucleus of the stria terminalis in the processing of anxiety and pain. Neuropsychopharmacology 2014;39:2633-2645.

153. Johnson AC, Tran L, Schulkin J, Greenwood-Van Meerveld B. Importance of stress receptor-mediated mechanisms in the amygdala on visceral pain perception in an intrinsically anxious rat. Neurogastroenterol Motil 2012;24:479-86, e219.

154. Su J, Tanaka Y, Muratsubaki T, Kano M, Kanazawa M, Fukudo $\mathrm{S}$. Injection of corticotropin-releasing hormone into the amygdala aggravates visceral nociception and induces noradrenaline release in rats. Neurogastroenterol Motil Published Online First: 31 Oct 2014. doi: $10.1111 /$ nmo. 12462 .

155. Van Bockstaele EJ, Colago EE, Valentino RJ. Amygdaloid corticotropin-releasing factor targets locus coeruleus dendrites: substrate for the co-ordination of emotional and cognitive limbs of the stress response. J Neuroendocrinol 1998;10:743-757.

156. Gray TS. Amygdaloid CRF pathways. Role in autonomic, neuroendocrine, and behavioral responses to stress. Ann N Y Acad Sci 1993;697:53-60

157. Kim SH, Han JE, Hwang S, Oh DH. The expression of corticotropin-releasing factor in the central nucleus of the amygdala, induced by colorectal distension, is attenuated by general anesthesia. J Korean Med Sci 2010;25:1646-1651.
158. Ji G, Fu Y, Ruppert KA, Neugebauer V. Pain-related anxiety-like behavior requires $\mathrm{CRF} 1$ receptors in the amygdala. Mol Pain 2007;3:13.

159. Rouwette T, Klemann K, Gaszner B, et al. Differential responses of corticotropin-releasing factor and urocortin 1 to acute pain stress in the rat brain. Neuroscience 2011;183:15-24.

160. Greenwood-Van Meerveld B, Johnson AC, Schulkin J, Myers DA. Long-term expression of corticotropin-releasing factor $(\mathrm{CRF})$ in the paraventricular nucleus of the hypothalamus in response to an acute colonic inflammation. Brain Res 2006;1071:91-96.

161. Nishii H, Nomura M, Aono H, Fujimoto N, Matsumoto T. Up-regulation of galanin and corticotropin-releasing hormone mRNAs in the key hypothalamic and amygdaloid nuclei in a mouse model of visceral pain. Regul Pept 2007;141:105-112.

162. Kosoyan HP, Grigoriadis DE, Taché $\mathrm{Y}$. The $\mathrm{CRF}_{1}$ antagonist, NBI-35965 abolished the activation of locus coeruleus by colorectal distention and intracisternal CRF in rats. Brain Res 2005;1056: 85-96.

163. Rouzade-Dominguez ML, Curtis AL, Valentino RJ. Role of Barrington's nucleus in the activation of rat locus coeruleus neurons by colonic distension. Brain Res 2001;917:206-218.

164. Lechner SM, Curtis AL, Brons R, Valentino RJ. Locus coeruleus activation by colon distention: role of corticotropin-releasing factor and excitatory amino acids. Brain Res 1997;756:114-124.

165. Kravets JL, Reyes BA, Unterwald EM, Van Bockstaele EJ. Direct targeting of peptidergic amygdalar neurons by noradrenergic afferents: linking stress-integrative circuitry. Brain Struct Funct Published Online First: 23 Nov 2013. doi: 10.1007/s00429-0130674-8.

166. Naliboff BD, Munakata J, Fullerton S, et al. Evidence for two distinct perceptual alterations in irritable bowel syndrome. Gut 1997;41:505-512.

167. Berridge CW. Noradrenergic modulation of arousal. Brain Res Rev 2008;58:1-17.

168. Barreau F, Cartier C, Leveque M, et al. Pathways involved in gut mucosal barrier dysfunction induced in adult rats by maternal deprivation: corticotrophin-releasing factor and nerve growth factor interplay. J Physiol 2007;580:347-356.

169. Eutamene H, Theodorou V, Fioramonti J, Bueno L. Acute stress modulates the histamine content of mast cells in the gastrointestinal tract through interleukin-1 and corticotropin-releasing factor release in rats. J Physiol 2003;553(Pt 3):959-966.

170. Larauche M. Novel insights in the role of peripheral corticotropin-releasing factor and mast cells in stress-induced visceral hypersensitivity. Neurogastroenterol Motil 2012;24:201-205.

171. Sengupta JN. Visceral pain: the neurophysiological mechanism. Handb Exp Pharmacol 2009;31-74.

172. Cervero F, Laird JM. Understanding the signaling and transmission of visceral nociceptive events. J Neurobiol 2004;61:45-54.

173. Teitelbaum AA, Gareau MG, Jury J, Yang PC, Perdue MH. Chronic peripheral administration of corticotropin-releasing factor causes colonic barrier dysfunction similar to psychological stress. Am J Physiol Gastrointest Liver Physiol 2008;295:G452-G459.

174. Soderholm JD, Perdue MH. II. Stress and intestinal barrier function. Am J Physiol Gastrointest Liver Physiol 2001;280:G7G13. 
175. Ait-Belgnaoui A, Bradesi S, Fioramonti J, Theodorou V, Bueno L. Acute stress-induced hypersensitivity to colonic distension depends upon increase in paracellular permeability: role of myosin light chain kinase. Pain 2005;113:141-147.

176. Million $\mathrm{M}$, Wang $\mathrm{L}$, Wang $\mathrm{Y}$, et al. $\mathrm{CRF}_{2}$ receptor activation prevents colorectal distension-induced visceral pain and spinal ERK1/2 phosphorylation in rats. Gut 2006;55:172-181.

177. Fukudo S, Nomura T, Hongo M. Impact of corticotropin-releasing hormone on gastrointestinal motility and adrenocorticotropic hormone in normal controls and patients with irritable bowel syndrome. Gut 1998;42:845-849.

178. Lembo T, Plourde V, Shui Z, et al. Effects of the corticotropin-releasing factor (CRF) on rectal afferent nerves in humans. Neurogastroenterol Motil 1996;8:9-18.

179. Nozu T, Kudaira M. Corticotropin-releasing factor induces rectal hypersensitivity after repetitive painful rectal distention in healthy humans. J Gastroenterol 2006;41:740-744.

180. Sagami Y, Shimada Y, Tayama J, et al. Effect of a corticotropin releasing hormone receptor antagonist on colonic sensory and motor function in patients with irritable bowel syndrome. Gut 2004;53: 958-964.

181. Tayama J, Sagami Y, Shimada Y, Hongo M, Fukudo S. Effect of alpha-helical $\mathrm{CRH}$ on quantitative electroencephalogram in patients with irritable bowel syndrome. Neurogastroenterol Motil 2007;19: 471-483.

182. Yuan PQ, Wu SV, Elliott J, et al. Expression of corticotropin releasing factor receptor type $1\left(\mathrm{CRF}_{1}\right)$ in the human gastrointestinal tract and upregulation in the colonic mucosa in patients with ulcerative colitis. Peptides 2012;38:62-69.

183. Wallon C, Persborn M, Jönsson M, et al. Eosinophils express muscarinic receptors and corticotropin-releasing factor to disrupt the mucosal barrier in ulcerative colitis. Gastroenterology 2011;140: 1597-1607.

184. Wallon C, Yang PC, Keita AV, et al. Corticotropin-releasing hormone $(\mathrm{CRH})$ regulates macromolecular permeability via mast cells in normal human colonic biopsies in vitro. Gut 2008;57:50-58.

185. Chadwick VS, Chen W, Shu D, et al. Activation of the mucosal immune system in irritable bowel syndrome. Gastroenterology 2002; 122:1778-1783.

186. Dinan TG, Quigley EM, Ahmed SM, et al. Hypothalamic-pituitary-gut axis dysregulation in irritable bowel syndrome: plasma cytokines as a potential biomarker? Gastroenterology 2006;130:304311.

187. Stasi C, Bellini M, Bassotti G, Blandizzi C, Milani S. Serotonin receptors and their role in the pathophysiology and therapy of irritable bowel syndrome. Tech Coloproctol 2014;18:613-621.

188. Williams JP. Corticotropin-releasing factor 1 receptor antagonists: a patent review. Expert Opin Ther Pat 2013;23:1057-1068.

189. Chen C. Recent advances in small molecule antagonists of the corticotropin-releasing factor type-1 receptor-focus on pharmacology and pharmacokinetics. Curr Med Chem 2006;13:1261-1282.

190. Tellew JE, Lanier M, Moorjani M, et al. Discovery of NBI-77860/GSK561679, a potent corticotropin- releasing factor (CRF1) receptor antagonist with improved pharmacokinetic properties. Bioorg Med Chem Lett 2010;20:7259-7264.

191. Zhuo X, Hartz RA, Bronson JJ, et al. Comparative biotransfor- mation of pyrazinone-containing corticotropin-releasing factor receptor-1 antagonists: minimizing the reactive metabolite formation. Drug Metab Dispos 2010;38:5-15.

192. Hodgetts KJ, Ge P, Yoon T, et al. Discovery of N-(1-ethylpropyl)[3-methoxy-5-(2-methoxy-4-trifluoromethoxyphenyl)-6-methylpyrazin-2-yl]amine 59 (NGD 98-2): an orally active corticotropin releasing factor-1 (CRF-1) receptor antagonist. J Med Chem 2011; 54:4187-4206.

193. Ising M, Zimmermann US, Kunzel HE, et al. High-affinity CRF1 receptor antagonist NBI-34041: preclinical and clinical data suggest safety and efficacy in attenuating elevated stress response. Neuropsychopharmacology 2007;32:1941-1949.

194. Bailey JE, Papadopoulos A, Diaper A, et al. Preliminary evidence of anxiolytic effects of the CRF1 receptor antagonist R317573 in the $7.5 \% \mathrm{CO}_{2}$ proof-of-concept experimental model of human anxiety. $\mathrm{J}$ Psychopharmacol 2011.

195. Schmidt ME, Andrews RD, van der Ark P, et al. Dose-dependent effects of the $\mathrm{CRF}_{1}$ receptor antagonist $\mathrm{R} 317573$ on regional brain activity in healthy male subjects. Psychopharmacology (Berl) 2010;208:109-119.

196. Hubbard CS, Labus JS, Bueller J, et al. Corticotropin-releasing factor receptor 1 antagonist alters regional activation and effective connectivity in an emotional-arousal circuit during expectation of abdominal pain. J Neurosci 2011;31:12491-12500.

197. Ji G, Neugebauer V. Differential effects of CRF1 and CRF2 receptor antagonists on pain-related sensitization of neurons in the central nucleus of the amygdala. J Neurophysiol 2007;97:38933904.

198. Neugebauer V, Li W, Bird GC, Han JS. The amygdala and persistent pain. Neuroscientist 2004;10:221-234.

199. Bouin M, Plourde V, Boivin M, et al. Rectal distention testing in patients with irritable bowel syndrome: sensitivity, specificity, and predictive values of pain sensory thresholds. Gastroenterology 2002; 122:1771-1777.

200. North CS, Hong BA, Alpers DH. Relationship of functional gastrointestinal disorders and psychiatric disorders: implications for treatment. World J Gastroenterol 2007;13:2020-2027.

201. Sweetser S, Camilleri M, Linker Nord SJ, et al. Do corticotropin releasing factor-1 receptors influence colonic transit and bowel function in women with irritable bowel syndrome? Am J Physiol Gastrointest Liver Physiol 2009;296:G1299-G1306.

202. Martinez V, Taché $Y$. $C_{R} F_{1}$ receptors as a therapeutic target for irritable bowel syndrome. Curr Pharm Des 2006;12:4071-4088.

203. Mahajan S, Liao M, Barkan P, Takahashi K, Bhargava A. Urocortin 3 expression at baseline and during inflammation in the colon: corticotropin releasing factor receptors cross-talk. Peptides 2014;54:58-66.

204. Fu Y, Neugebauer V. Differential mechanisms of CRF1 and CRF2 receptor functions in the amygdala in pain-related synaptic facilitation and behavior. J Neurosci 2008;28:3861-3876.

205. Zorrilla EP, Logrip ML, Koob GF. Corticotropin releasing factor: a key role in the neurobiology of addiction. Front Neuroendocrinol 2014;35:234-244.

206. Gravanis A, Margioris AN. The corticotropin-releasing factor (CRF) family of neuropeptides in inflammation: potential therapeutic applications. Curr Med Chem 2005;12:1503-1512. 
207. Holsboer F, Ising M. Central CRH system in depression and anxiety--evidence from clinical studies with CRH1 receptor antagonists. Eur J Pharmacol 2008;583:350-357.

208. Paez-Pereda M, Hausch F, Holsboer F. Corticotropin releasing factor receptor antagonists for major depressive disorder. Expert Opin Investig Drugs 2011;20:519-535.

209. Santos J, Alonso C, Vicario M, Ramos L, Lobo B, Malagelada JR.
Neuropharmacology of stress-induced mucosal inflammation: implications for inflammatory bowel disease and irritable bowel syndrome. Curr Mol Med 2008;8:258-273.

210. Stengel A, Taché Y. Neuroendocrine control of the gut during stress: corticotropin-releasing factor signaling pathways in the spotlight. Annu Rev Physiol 2009;71:219-239. 